\title{
Pelatihan Sistem Pengarsipan Data Berebasis WEB pada Tenaga Admin Fakultas Keguruan dan Ilmu Pendidikan Universitas Mataram
}

\author{
Amrullah$^{1}$, M. Makhrus ${ }^{2}$, S. Hadisaputra ${ }^{3}$, M. L. Ilhamdi ${ }^{4}$ I.M. Sujana ${ }^{5}$ \\ ${ }^{1}$ Program Studi Pendidikan Matematika, FKIP Universitas Mataram, Mataram, Indonesia \\ ${ }^{2}$ Program Studi Pendidikan Fisika, FKIP Universitas Mataram, Mataram, Indonesia \\ ${ }^{3}$ Program Studi Pendidikan Kimia, FKIP Universitas Mataram, Mataram, Indonesia \\ ${ }^{4}$ Prgram Studi Pendidikan Biologi, FKIP Universitas Mataram, Mataram, Indonesia \\ ${ }^{5}$ Program Studi Pendidikan Bahasa Inggris, FKIP, Universitas Mataram,Mataram, Indonesia
}

DOI: https://doi.org/10.29303/jpmsi.v2i1.9

Citation: Amrullah, Makhrus. M., Hadisaputra, S., Ilhamdi, M.L., Sujana, I.M. 2020. Pelatihan Sistem Pengarsipan Data Berebasis WEB pada Tenaga Admin Fakultas Keguruan dan Ilmu Pendidikan Universitas Mataram. Jurnal Pengabdian Masyarakat Sains Indonesia (JPMSI). 2(1): .

Article history

Received: November $11^{\text {th }} 2019$

Revised: April $06^{\text {th }} 2020$

Accepted: April $11^{\text {th }} 2020$

*Corresponding Author:

Amrullah, Program Studi

Pendidikan Bahasa Inggris,

Universitas Mataram,

Indonesia;

Email: amrullah@unram.ac.id

\begin{abstract}
Abstrak: Kegiatan pelatihan sistem pengarsipan ini bertujuan untuk meningkatkan kemampuan dan keterampilan tenaga admin dalam mengelolah dokumen berbasis website pada Fakultas Keguruan dan Ilmu pendidika Universitas Mataram. Kegiatan ini merupakan bentuk pengabdian dan aplikasi keilmuan pada masyarakat khususnya warga FKIP universitas Mataram. Pengarsipan merupakan hal penting dalam menyimpanan dokumen sehingga memudahkan dalam proses pencarian dan penelusuran kembali data yang telah disimpan. Kegiatan ini terdiri dari pembuatan aplikasi online menggunakan PHP dan database MySQL, dan pelatihan penggunaan aplikasi pada tenaga admin di setiap unit FKIP. Secara keseluruhan kegiatan ini berjalan dengan baik dan tenaga admin berhasil melakukan input data pengarsipan berbasis website
\end{abstract}

Kata kunci: pengarsipan, PHP, MySQL, online

\section{Pendahuluan}

Infomasi lembaga merupakan hal penting untuk memperkenalkan identitas dan aktivitas yang ada dalam suatu lembaga. Infomasi tersebut dapat disalurkan melalui berbagai media antara lain surat kabar, brosur maupun website. Informasi dari Lembaga dapat berupa dokumen pengumuman, dokumen umum maupun dokumen bersifat provat atau pribadi. Berbagai dokumen tersebut dapat disimpan secara elektronik baik secara off-line maupun online. Pada saat ini, pengaruh perkembangan teknologi yang semakin baik menyebabkan pencari informasi cenderung menggunakan internet melalui website, blog atau media sosial lainnya. Website merupakan keseluruhan halaman-halaman infomasi yang saling terhubung pada sebuah domain. Website server adalah sebuah perangkat lunak dalam server yang dapat mejalankan permintaan (request) berupa halaman web melalui HTTP atau HTTPS dari browser serta mersepon kembali permintaan tersebut. Domain merupakan suatu nama yang bersifat unik pada suatu lembaga atau sebuah institusi sehingga bisa di akses melalui internet (Yuhefizar, 2013 ). Beberapa lembaga menyiapkan unit-unit khusus yang mengurusi hal tersebut. Hal itu penting dilakukan karena diperlukan keberlanjutan dan kemutakhiran serta penyimpanan informasi atau dokumen atau infomasi dengan aman dan mudah akses seperti pada website atau media sosial lain nya. Website sebagai media infomasi untuk publik tidak hanya pembuatan atau penggadaan yang penting dilakukan. Namun menjaga keamanannya serta kemutakhiran data dalam conten webside jauh lebih penting untuk diperhatikan oleh suatu lembaga. Selain terupdatenya data infomasi, optimasi kontet perlu dilakukan. Hampir semua dokumen dapat disimpan dalam dunia internet. Salah satu website yang memiliki pelayanan yang handal saaat ini mesin pencari seperti Google, Yahoo dan lain-lain. Mesin 
Amrullah et al, Jurnal Pengabdian Masyarakat Sains Indonesia 2020, 2 (1):57-62 DOI : https://doi.org/10.29303/ipmsi.v2i1.9

pencari secara teratur mengindex konten-konten terbaru pada suatu website dan menyimpannya dalam basis data mereka.

Update konten secara berkala bertujuan untuk membangun website yang berkualitas dan kuat. Tapi tidak sembarang konten, buatlah serelevan mungkin dengan isi website Anda. Berikut adalah faktor yang paling penting dalam isi konten website Anda misalnya kata kunci. Kata Kunci adalah inti utama dari keberhasilan pencarian suatu konten website. Jika tidak ditemukan kata kunci yang tepat untuk website, maka infomasi itu menjadi tidak jelas dan dilewati begitu saja oleh mesin pencari.

FKIP sebagai lembaga akademik yang terdiri dari 10 program studi telah memiliki website, namun informasi dan kegiatan terbaru jarang diupdate pada website FKIP. Terkandang suratsurat penting hanya dapat disebarkan dengan whatsapp atau media lainnya. Selama ini, Website FKIP hanya dikelola dan diupdate oleh bagian laboatorium multimedia yang memiliki pegawai 1 atau 2 orang saja. Oleh karena itu informasi dan aktivitas pada 10 studi tidak dapat terupdate secara optimal. Oleh karena itulah diperlukan usaha untuk menambah dan meningkatan kualitas SDM yang dapat menanggani website pengrasipan data FKIP. Database website ini menggunakan MySql dengan Bahasa pemrograman PHP. MySQL merupakan suatu system database berbasis server yang dapat digunakan multiuser dengan tingkat keamanan tinggi.

Dabase MySQL lebih banyak digunakan untuk database berbasis website yang menggunakan bahasa pemrograman PHP (Rudianto, Arief M. 2011). Bahasa pemrograman PHP adalah bahasa pemrogramman yang memiliki kemampuan dalam mengelolah infomasi berbasis web (Elisa U., YanaY., \& Noor R. 2012). Database adalah system data atau kumpulan data yang diatur dengan aturan tertentu sehingga dapat ditelusuri secara cepat dan tepat (Fathul Wahid, 2001).

Selain itu, website FKIP belum menyediakann system yang dapat menyimpan dokumen untuk setiap unit di FKIP dengan optimal. Hal ini dapat dilihat dari indikator kesulitan menemukan dokumen tertentu di lingkungan FKIP Universitas Mataram. Lebih lanjut melalui pengabdian ini, dilakukan sosialisasi dan pelatihan pengarsipan data pada website FKIP. Kegiatan pengabdian ini dapat meningkatan pengetahuan dan ketrampilan pengarsipan dokumen pada aplikasi pengarsipan di lingkungan FKIP Universitas Mataram.

\section{Metode}

Untuk mencapai tujuan kegiatan yaitu diperoleh aplikasi pengarsipan dokumen secara online atau berbasis website. Dokumen merupakan semua jenis infomasi berupa file atau berkas yang diterima atau keluarkan (Wursanto,1991).

Kegiatan ini diharapkan dapat meningkatkan ketrampilan tenaga admin dilingkungan FKIP Universitas Mataram diperlukan langkah-langkah sebgai berikut

1. Analisis Jenis dokumen serta hak akses dokumen.

- Arsip bersifat umum. Arsip ini dapat diakses oleh siapa saja.

- Arsip bersifat privat pada bebeerapa unit fakultas. Arsip yang bersifat privat pada unit adalah dokumen yang hanya bias diakses oleh unit itu tau unit diatas unit tersebut.

- Arsip Pimpinan. Arsip ini hanya dapat diakses oleh Pimpinan. Dalam hal ini di FKIP, yang dimaksud dengan pimpinan adalah Dekan, Wakil Dekan 1 (WD1), WD2 dan WD3. Selain dokumen yang bersifat privat untuk pimpina, system pengarsipan juga mengijinkan pimpinan dapat mengakses semua dokumen pada unit dibawahnya.

2. Pembuatan Aplikasi paengarsipan secara online

Aplikasi ini dibuat menggunakan Bahasa pemrograman PHP dan menggunakan database MYSQL.

3. Pelatihan tenaga admin dalam penggunaan aplikasi pengrasipan.

Pelatiahn merupakan bagian sosialisasi cara dan manfaat penggunakan aplikasi pengrasipan secara online untuk memudahkan menelusuran dokumen pada FKIP Unram.

\section{Hasil dan Pembahasan}

Berdasarkan observasi dokumen di FKIP, diperoleh 3 (tiga) jenis dokumen yang digunakan dalamkampus ini. Berikut jenis dokumen yang dikenal.

1. Arsip bersifat umum. Arsip ini dapat diakses oleh siapa saja. Oleh karena itu pengaksesan data yang bersifat umum dapat dilakakan tanpa verifikasi user dan password. Beberapa dokumen yang besifat umum diantaranya 
Amrullah et al, Jurnal Pengabdian Masyarakat Sains Indonesia 2020, 2 (1):57-62 DOI : https://doi.org/10.29303/ipmsi.v2i1.9

dalah dokumen pengumuman, dokumen himbauan, dokumen kurikulum, dokumen profil baik profil fakultas maupun profil unit dibawah fakultas.

2. Arsip bersifat privat pada bebeerapa unit fakultas.

Arsip yang bersifat privat pada unit adalah dokumen yang hanya bias diakses oleh unit itu tau unit diatas unit tersebut. Sebagai contoh kasus, unit program studi Pendidikan matematika, Pendidikan Fisika, Pendidikan Biologi dan Pendidikan Kimia berada dalam jurusan Pendidikan MIPA. Oleh karena itu, semua dokumen yang bersifat privat pada program studi Pendidikan Matematika hanya bias diakses oleh semua user dalam unit program studi Pendidikan Matematika dan user pimpinan yang ada pada jurusan Pendidikan MIPA. Sedangkan User pada unit program studi Pendidikan Fisika tidak dapat mengakses dokumen pada program studi Matematika demikian juga sebaliknya.

3. Arsip Pimpinan.

Arsip ini hanya dapat diakses oleh Pimpinan. Dalam hal ini di FKIP, yang dimaksu dengan

Berikut Bagan jenis dan hak akses pengunaan arsip pada setiap unit di FKIP
e-ISSN : 2715-2537

p-ISSN : 2715-2545

pimpinan adalah Dekan, Wd1, WD2 dan WD3. Selain dokumen yang bersifat privat untuk pimpina, system pengarsipan juga mengijinkan pimpinan dapat mengakses semua dokumen pada unit dibawahnya.

Berdasarkan ketiga jenis arsip tersebut, maka dilakukan perancangan system pengarsipan berbasis website yang bersifat umum, privat unit dan privat pimpinan.

Privat unit terbagi atas sejumlah unit yang ada pada FKIP. Pengatur hak akses sangat penting dilakukan untuk memberikan kepastian privasi terhadapat dokumen tertentu. Dengan fasiltas hak akses ini hanya user yang dijinkan yang dapat mengakses suatu file berdasarkan kondisi unit yang diguakan. Hak akse ini diperlukan autentifikasi menggunakan username dan password. Selain Pengakses dokumen, autentifikasi diperlukan dalam proses input data. Sebab tidak sebarang dokumen dapat diijin masuk ke dalam system sehingga data atau dokumen yang masuk ke dalam aplikasi hanya data-data yang bermanfaat secara Lembaga. Secara umum urutan hak akses dapat digambarkan seperti pada Gambar 1.

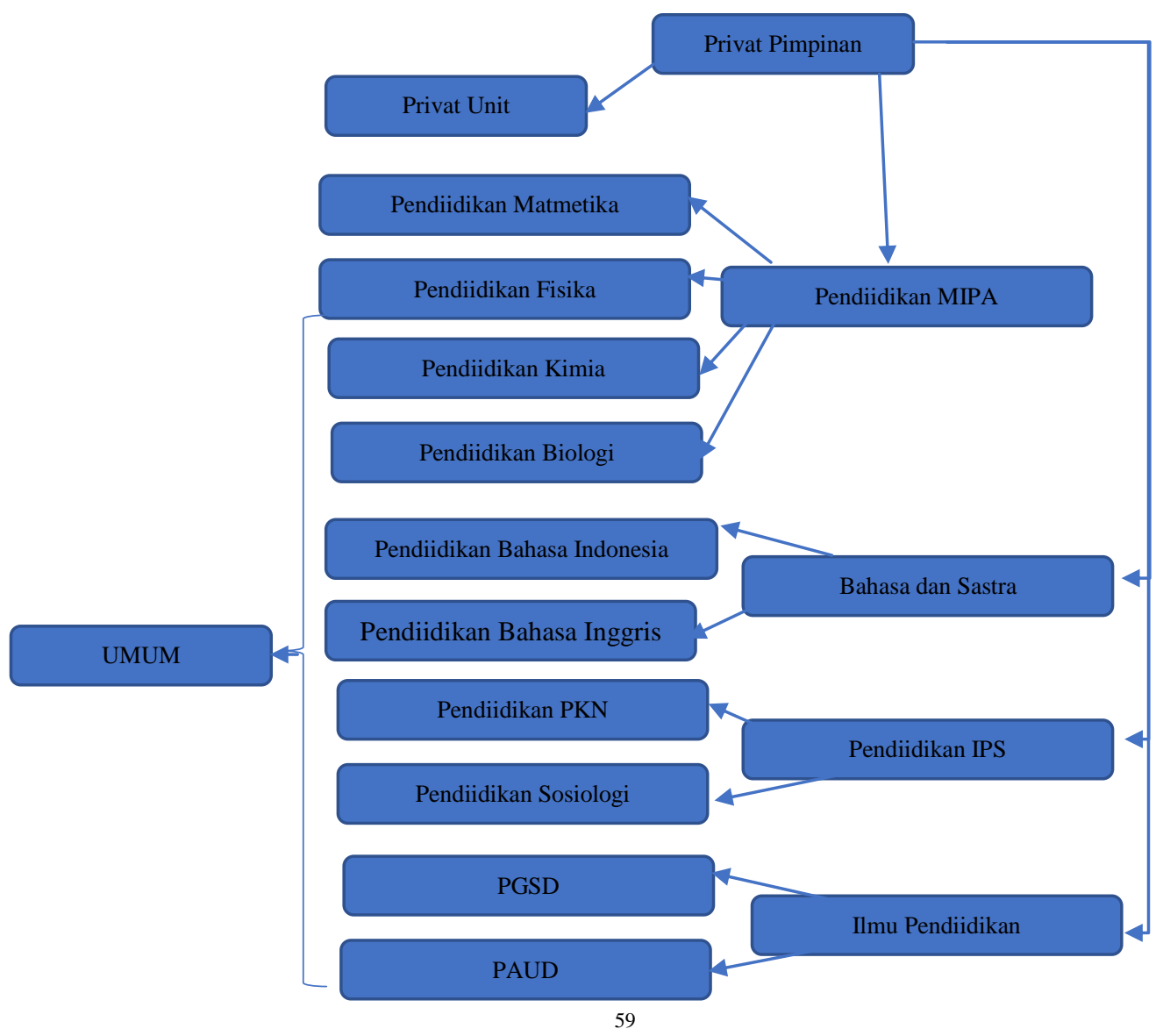


1. Implentasi Pengarsipan.

\section{Gambar 1. Alur Hak Akses User}

Aplikasi pengarsipan dibuat dengan menggunakan Bahasa pemrogaman PHP dengan database MYSQL. Aplikasi pengarispan telah bersifat online dengan alamat URL: http://fkip.unram.ac.id/lab/arsip.php

Berikut tampilan untuk melihat surat atau arsip yang bersifat umum seperti pada Gambar 2 berikut ini.

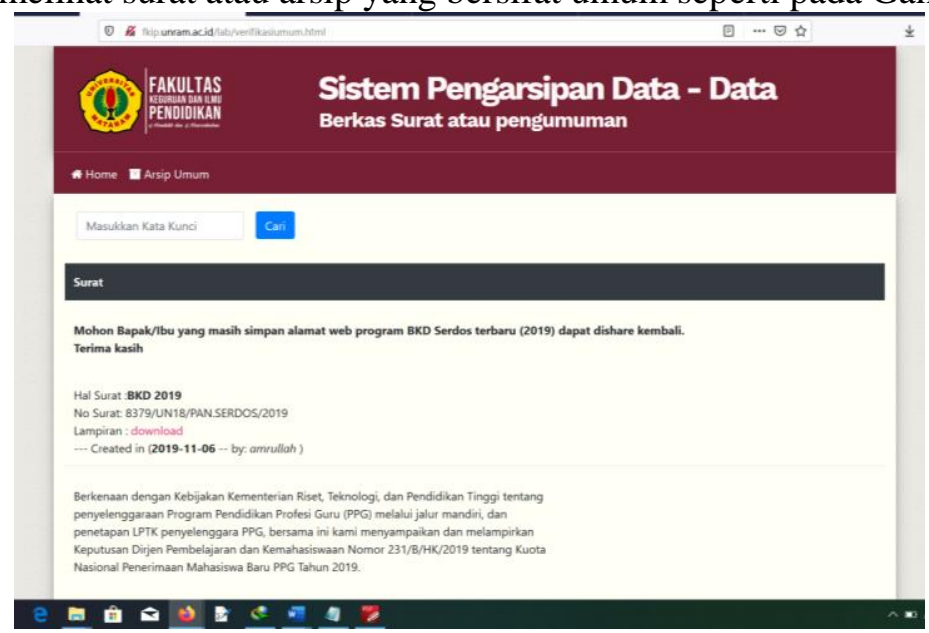

2. Proses Input data

Gambar 2. Tampilan Depan Aplikasi Pengarsipan

Data dokumen pengrasipan dinput oleh admin pada setiap unit. Admin telah diberi hak untuk menginput dengan menyiapkan berbagai hal. Hal yang harus diperhatikan dalam proses input data adalah sebagai berikut

a) Hal surat

b) No Surat

c) Tanggal Surat

d) Isi atau informasi tentang surat. Hal ini penting dinput sebagai bahan atau kata kuci untuk proses pencarian pada saat dibutuhkan

e) Dokumen sudah dalam bentuk file.

Berikut gambar tampilan proses input data pada system pengarsipan seperti pada Gambar 3 berikut ini .

3. Implentasi Pengarsipan.

Aplikasi pengarsipan dibuat dengan menggunakan Bahasa pemrogaman PHP dengan database MYSQL. Aplikasi pengarispan telah bersifat online dengan alamat URL: http://fkip.unram.ac.id/lab/arsip.php. Berikut tampilan untuk melihat surat atau arsip yang bersifat umum seperti pada Gambar 2 berikut ini.

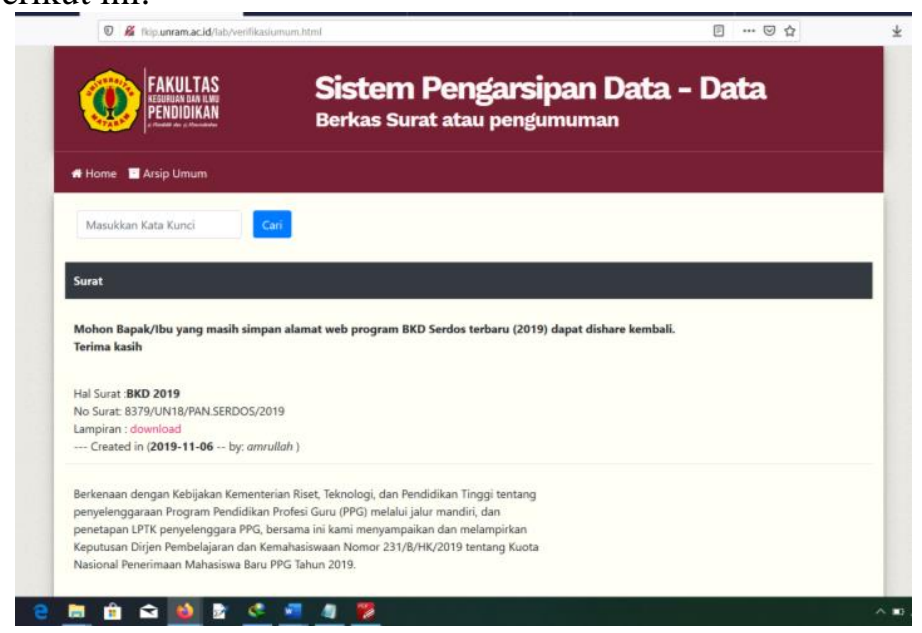




\section{Proses Input data}

Gambar 2. Tampilan Depan Aplikasi Pengarsipan

Data dokumen pengrasipan dinput oleh admin pada setiap unit. Admin telah diberi hak untuk menginput dengan menyiapkan berbagai hal. Hal yang harus diperhatikan dalam proses input data adalah sebagai berikut

f) Hal surat

g) No Surat

h) Tanggal Surat

i) Isi atau informasi tentang surat. Hal ini penting dinput sebagai bahan atau kata kuci untuk proses pencarian pada saat dibutuhkan

j) Dokumen sudah dalam bentuk file.

Berikut gambar tampilan proses input data pada system pengarsipan seperti pada Gambar 3 berikut ini .

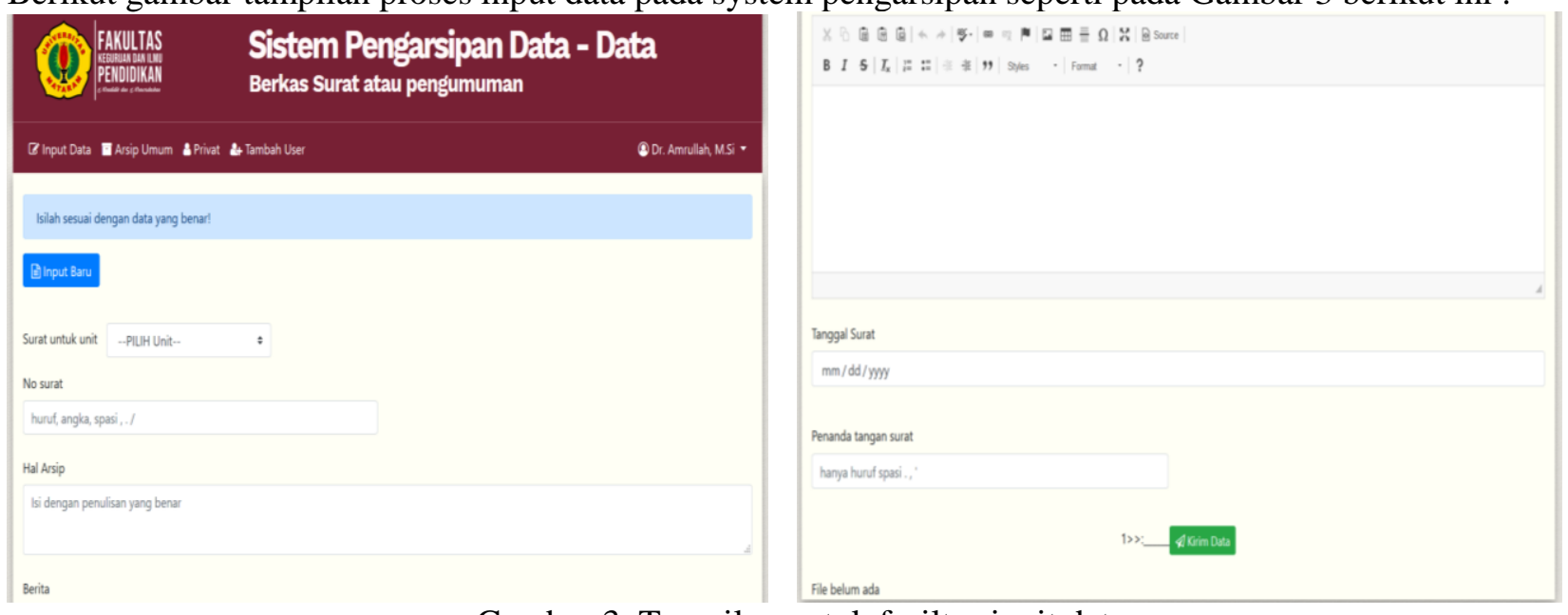

Gambar 3. Tampilan untuk fasiltas inpit data

\section{User ADMIN}

User admin bertugas mengatur dan mengelolah user-user lain dalam system. Pada system ini, admin dapat menambah user yang dapat mengakses dan memasukan data kedalam system. Berikut tampilan fasillitas pada user sebagai admin pada Gambar 4 berikut ini.

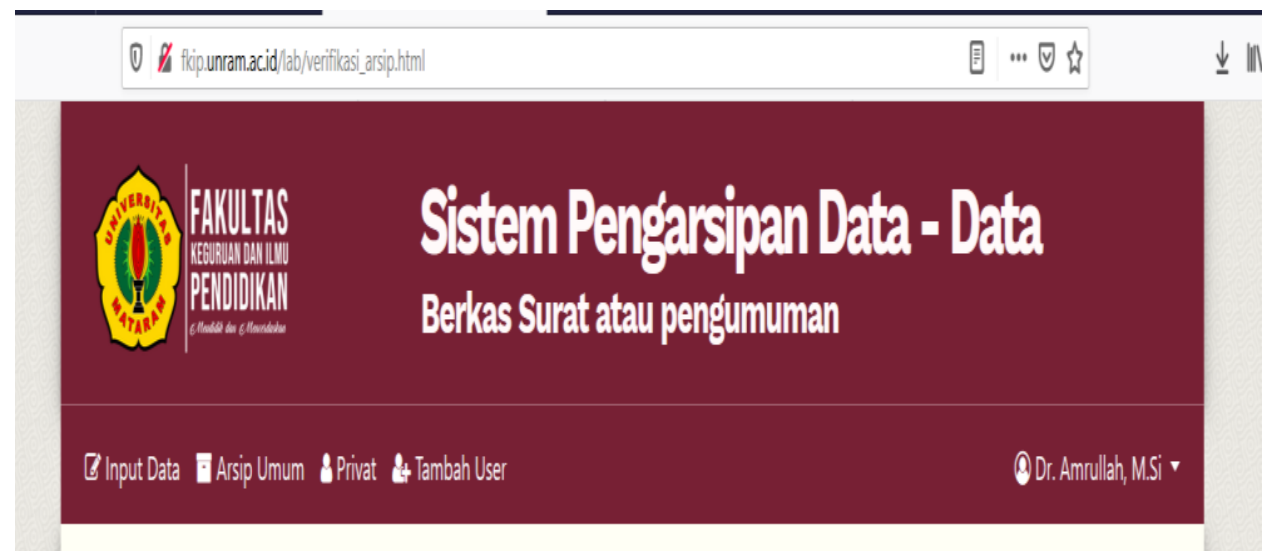

Gambar 4. Failitas pada User Admin

Pada fasilitas ini, user adamin terdapat lima menu utama yaitu,

a) input data

b) Akses arsip umum

c) Akses arsip privat 
d) Akses Penambahan User

e) Pengaturan akun seperti penggantian password dll.

Selain itu, user dalam system ini dapat mencari arsip yang ada ssesuai hak akses dengan fasilitas pencarian dengan memassukan kata kunci pencarian diakhir dengn klik cari seprti pda Gambar 5. berikut ini.

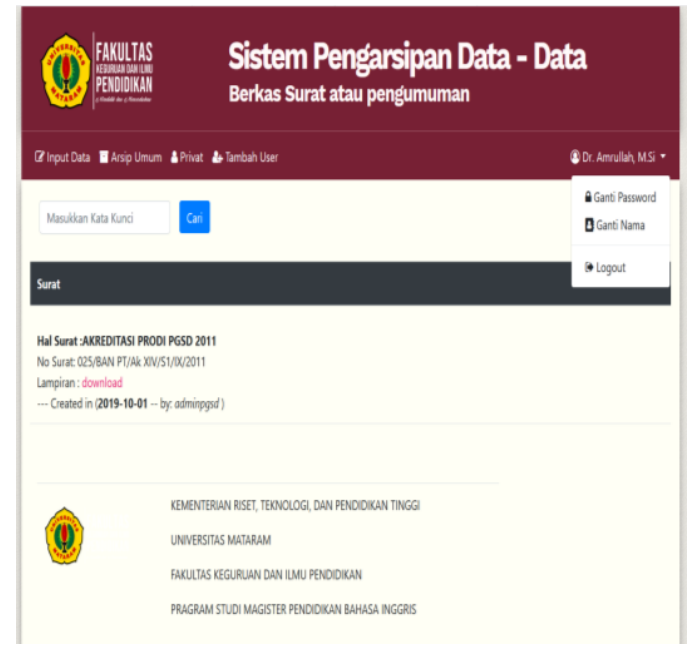

\section{Kesimpulan}

Aplikasi ini telah dapat digunakan secara online untuk mendata dan mengarsipkan setiap dokumen pada fakultas keguruan dan ilmu Pendidikan Universitas Mataram. Setiap dokumen dapat dicari dengan mudah pada system ini. Pembagian hak akses digunakan untuk membatas privasi setiap unit dalan FKIP Universitas Mataram..

\section{Saran}

Diharapkan FKIP dapat menggunakan aplikasi ini secara optimal untuk pengarsipan berkan secara online.

Diharap adaa pelatihan lebih lanjut untuk pengotimalan ketrampilan tenaga admin dalam menggnakan aplikasi ini

\section{Ucapan Terima Kasih}

Penulis mengucapkan terima kasih kepada Fakutas Keguruan dan Ilmu Pendidikan yang telah mendanai kegitan pengabdian ini tahun 2019

\section{Daftar Pustaka}

Anhar, (2010). Panduan Menguasai PHP \& MySQL Secara Otodidak, Mediakita, Jakarta.
A.W.Widjaja.(2006). Administraasi Kepegawaian. Rajawali Pres, Jakarta .

Bunafit, Nugroho. (2004), PHP dan MySQL dengan editor dreamweaver MX ANDI, Yogyakarta.

Didik Dwi Prasetyo. (2004). Aplikasi Database Client/Server Menggunakan Delphi dan MySQL. PT.Elex Media Komputindo. Jakarta.

Elisa U., YanaY., \& Noor R. (2012). Rancang Bangun Sistem Informasi Jadwal Perkuliahan Berbasis Jquery Mobile Dengan Menggunakan PHP dan MySQL, Jurnal Infotel vol 4 No 2

Fathul, Wahid, (2001), Pengantar dan Konsep Database, PT.Elex Media Komputindo, Jakarta

Yuhefizar.2013, Cara Mudah dan Murah Membangun dan Mengelola WEBSITE.Yogyakarta.Graha Ilmu

Rudianto, Arief M. (2011). PemrogramanWeb Dinamis menggunakan PHP dan MySQL. Yogyakarta: Andi Offset

Wursanto, H. (1991). Pembimbing Administrasi dan Surat-Menyurat. Yogyakarta: Andi. 